\title{
Carbon supported manganese(IV)-cobalt(II/III) oxides nanoparticles for high-performance electrochemical supercapacitors
}

\author{
Jolita Jablonskienë $\dot{e}^{*}$ \\ Dijana Šimkūnaitè, \\ Jūratė Vaičiūnienè, \\ Giedrius Stalnionis, \\ Audrius Drabavičius, \\ Loreta Tamašauskaitè-Tamašiūnaitè, \\ Eugenijus Norkus \\ Center for Physical Sciences \\ and Technology, \\ 3 Sauletekio Avenue, \\ 10257 Vilnius, Lithuania
}

The carbon supported manganese(IV)-cobalt (II/III) oxides nanoparticles labelled as $\mathrm{MnO}_{2}-\mathrm{Co}_{3} \mathrm{O}_{4} / \mathrm{C}$ nanocomposites have been prepared by a simple one-step microwave-assisted heating method using different precursor materials. Scanning electron microscopy (SEM), transmission electron microscopy (TEM) and inductively coupled plasma optical emission spectroscopy (ICP-OES) have been used for the characterization of morphology, structure and composition of the synthesized nanocomposites, whereas the electrochemical performance of the prepared nanocomposites has been evaluated by using cyclic voltammetry $(\mathrm{CV})$.

It was determined that the use of different precursor materials for the synthesis of the carbon supported $\mathrm{MnO}_{2}$ and $\mathrm{Co}_{3} \mathrm{O}_{4}$ nanocomposites results in a different morphology of the prepared substances. A high specific capacitance $(C)$ of $658.8 \mathrm{~F} \mathrm{~g}^{-1}$ at a scan rate of $10 \mathrm{mV} \mathrm{s}^{-1}$ in a $1 \mathrm{M} \mathrm{Na}_{2} \mathrm{SO}_{4}$ solution has been obtained for the $\mathrm{MnO}_{2}-$ $\mathrm{Co}_{3} \mathrm{O}_{4} / \mathrm{C}-2$ nanocomposite that has a spherical shape of nanoparticles. Moreover, it significantly outperforms the $\mathrm{MnO}_{2}-\mathrm{Co}_{3} \mathrm{O}_{4} / \mathrm{C}-1$ nanocomposite that has a lamellar shape of nanoparticles.

Keywords: manganese, cobalt, carbon, nanocomposites, supercapacitors

\section{INTRODUCTION}

Supercapacitors (SCs) have gained increasing attention due to their high power density, long cycle life, fast charge/discharge rate, and in recent years are seriously viewed as potential candidates of next-generation energy storage devices [1, 2, 2 . They are especially valued for lightness and flexibility determining their large-scale of possible applications ranging from consumer electronic or portable devices like mobile phones, computers and memory back-up systems to hybrid electric vehicles or even

\footnotetext{
* Corresponding author. Email: jolita.jablonskiene@ftmc.lt
}

large industrial machinery, for defense and military or space equipment [3, 4 ].

The key issues in the commercial success of SCs application are directly linked to the selection and fabrication of the new, low-cost and efficient electrode materials offering a high potential for the substantially enhanced energy densities [3, 5. Based on different energy storage principles, supercapacitors are generally categorized into electrochemical double-layer capacitors that use large surface-area carbon materials [6-8] and pseudocapacitors that use transition metal oxides (TMOs) as active materials. Among the emerging electrode materials for pseudocapacitors, 
nanoscaled or mixed TMOs such as $\mathrm{RuO}_{2}, \mathrm{MnO}_{2}$, $\mathrm{Co}_{3} \mathrm{O}_{4}, \mathrm{NiO}, \mathrm{Fe}_{3} \mathrm{O}_{4}$ and $\mathrm{V}_{2} \mathrm{O}_{5}$ are the most attractive materials for their high theoretical specific capacitances $\left(C_{\mathrm{s}}\right)$, originating from fast and reversible redox reactions with the electrolyte ions [3].

Nevertheless, Ru-based materials dominate. They are most extensively explored due to the ultrahigh theoretical specific capacitance of $\mathrm{RuO}_{2}$ (reaching over $1300 \mathrm{~F} \mathrm{~g}^{-1}$ ), exceptional properties, including metallic-type conductivity, wide potential window and highly reversible redox reaction [9, 10]. But the relatively high cost, toxicity and limited environmental distribution of $\mathrm{RuO}_{2}$ restrict its large-scale commercial application in SCs. On the contrary, TMOs, specially $\mathrm{Co}_{3} \mathrm{O}_{4}$ [11-13] and $\mathrm{MnO}_{2}$ [14, 15, are considered rather promising electrode materials for SCs, since both of them are low priced, abundant, environment- friendly materials that are rich in oxidation states for efficient charge transfer, have various morphologies and exceptionally high theoretical specific capacitances $\left(C_{s}\right)$ of 3560 or $1370 \mathrm{~F} \mathrm{~g} \mathrm{~g}^{-1}$, respectively. However, regardless the fascinating characteristics typically TMOs suffer from their low actual specific capacitance due to poor conductivity and electrochemical stability, low contacting area with the electrolytes and structural degradation during the charge-discharge process [16, 17]. In order to improve the capacitive performance of TMOs nanostructured electrode material with various morphologies that have a high specific surface area and a large surfaceto-volume ratio for more effective contact with electrolyte ions, such as mesoporous $\mathrm{MnO}_{2}$ nanotubes/nanosheets [18], nanowires [19] or flowerlike, urchin-like and nanorod-like structures [20] or ultra-small $\mathrm{Co}_{3} \mathrm{O}_{4}$ nanocubes [21], hollow coral-shaped nanostructures [12] or nanosheets [22] have been created. Incorporation of foreign conductive metals including $\mathrm{Au}, \mathrm{Al}, \mathrm{Cu}, \mathrm{Fe}, \mathrm{Mg}$ and $\mathrm{Co}$ [23-30] into TMOs lattices has been successfully applied and revealed the increase in $C_{s}$, for example, in the presence of Co the achieved $C_{s}$ value was of $350 \mathrm{~F} \mathrm{~g}^{-1}$ at a current density of $0.1 \mathrm{~A} \mathrm{~g}^{-1}$ [29]. Analogously, creating binary, ternary or multy-mixed TMOs allowed improving the capacitive performance of those electrode materials, compared to that of the single metal compounds [31-35]. Among them, for example, are ultrathin amorphous $\mathrm{Co}-\mathrm{Fe}-\mathrm{B}$ nanosheets deposited on the 3-dimensional nickel foam substrate with $C_{s}$ of ca. $981 \mathrm{~F} \mathrm{~g}^{-1}$ at $1 \mathrm{~A} \mathrm{~g}^{-1}$ [31]; $\mathrm{Mn}-$ Co-Fe ternary hydroxide nanoplatelets directly settled on $\mathrm{Ni}$ foam delivering the maximum $C_{s}$ of $1200 \mathrm{~F} \mathrm{~g}^{-1}$ at a scan rate of $5 \mathrm{mV} \mathrm{s}^{-1}$ [32]; the $\mathrm{Co}_{3} \mathrm{O}_{4} @ \mathrm{PPy} @ \mathrm{MnO}_{2}$ 'core-shell-shell' nanowire arrays on the nickel foam substrate exhibited a prominent electrochemical performance with a high energy density of $34.3 \mathrm{Wh} \mathrm{kg}^{-1}$ at a power density of $80.0 \mathrm{~W} \mathrm{~kg}^{-1}$ [33]; $\mathrm{MnO}_{2} / \mathrm{Ni}(\mathrm{OH})_{2} / \mathrm{NF}$ composite with high $C_{s}$ of $506 \mathrm{~F} \mathrm{~g}^{-1}$ at $16.7 \mathrm{~A} \mathrm{~g}^{-1}$ [34]; tremella-like $\mathrm{NiO} @ \mathrm{Co}_{3} \mathrm{O}_{4} @ \mathrm{MnO}_{2}$ particles offered high $C_{s}$ of $792.6 \mathrm{~F} \mathrm{~g}^{-1}$ at $2 \mathrm{~A} \mathrm{~g}^{-1}$ [35]. The flower-like $\mathrm{Co}_{3} \mathrm{O}_{4} @ \mathrm{MnO}_{2}$ core-shell microspheres coated on nikel foam exhibited a significantly enhanced $C_{s}$ of $671 \mathrm{~F} \mathrm{~g}^{-1}$ at $1 \mathrm{~A} \mathrm{~g}^{-1}$ [36]. Furthermore, in order to overcome the abovementioned drawbacks, combining TMOs with high conductive substrates such as graphene, porous carbon, carbon nanotubes, activated carbon or carbon fiber is regarded not only an effective way to improve the electrochemical performance of SCs, but makes those materials rather attractive for fabricating flexible electrode materials with the aim to apply them as flexible, light and inexpensive energy storage devices. Recently, due to the synergic effect $\mathrm{Co}-\mathrm{Co}_{3} \mathrm{O}_{4} @$ carbon-nanotube $(\mathrm{CNT})$-incorporated $\mathrm{N}$-doped carbon $\left(\mathrm{C}_{\mathrm{s}}\right.$ of $671 \mathrm{~F} \mathrm{~g}^{-1}$ at $1 \mathrm{~A} \mathrm{~g}^{-1}$ ) [37] or in situ fabricated $\mathrm{MnO}_{2}$ and its derived $\mathrm{FeOOH}$ nanostructures on mesoporous carbon [38] further enhance the electrochemical performance of those TMOs stuctures and showed a great potential in application for energy storage devices. The core-shell nanostructured TMOs have shown to be more stable, and able for providing an outstanding cycling stability at a high current density. Among them are the hierarchical core-shell $\mathrm{NiCo}_{2} \mathrm{O}_{4} @ \mathrm{NiMoO}_{4}$ nanowires grown on carbon cloth [39] or manganese-nickel-cobalt sulfide (MNCS) multi-tripod nanotube arrays (NTAs) on a carbon nanotube fibers (CNTFs) surface [40], which could serve as flexible binder-free electrode materials for supercapacitors.

Herein, we demonstrate a facile microwave-assisted heating method for the synthesis of carbon supported $\mathrm{MnO}_{2}-\mathrm{Co}_{3} \mathrm{O}_{4}$ nanocomposites using different precursor materials with the aim to apply them as material for electrochemical supercapacitors. 


\section{EXPERIMENTAL}

\section{Preparation of nanocomposites}

The $\mathrm{MnO}_{2}-\mathrm{Co}_{3} \mathrm{O}_{4}$ nanocomposite supported on carbon was prepared in two different ways by the microwave-assisted heating. In the first way, $0.2 \mathrm{~g}$ of $\mathrm{KMnO}_{4}, 0.737 \mathrm{~g}$ of $\mathrm{Co}\left(\mathrm{NO}_{3}\right)_{2} \cdot 7 \mathrm{H}_{2} \mathrm{O}$ and $0.1 \mathrm{~g}$ of carbon powder were dispersed in $20 \mathrm{ml}$ of deionized water. The obtained reaction mixture was put into a microwave reactor Monowave 300 (Anton Paar) for $5 \mathrm{~min}$ at $150^{\circ} \mathrm{C}$ temperature. The precipitate was filtered out, washed with water and dried in a vacuum oven at $80^{\circ} \mathrm{C}$ temperature for $4 \mathrm{~h}$. The prepared nanocomposite was labelled as $\mathrm{MnO}_{2}-\mathrm{Co}_{3} \mathrm{O}_{4} / \mathrm{C}-1$. In the second way, $0.2 \mathrm{~g}$ of $\mathrm{KMnO}_{4}, 0.01 \mathrm{~g}$ of $\mathrm{Co}_{3} \mathrm{O}_{4}$ and $0.1 \mathrm{~g}$ of carbon powder were dispersed in $20 \mathrm{ml}$ of deionized water. The synthesis of nanocomposite was carried out at the same conditions. The prepared nanocomposite was labelled as $\mathrm{MnO}_{2}-\mathrm{Co}_{3} \mathrm{O}_{4} / \mathrm{C}-2$. Notably, $\mathrm{Co}_{3} \mathrm{O}_{4}$ was prepared by annealing of $\mathrm{Co}\left(\mathrm{NO}_{3}\right)_{2} \cdot 7 \mathrm{H}_{2} \mathrm{O}$ in air atmosphere in a muffle furnace at $400^{\circ} \mathrm{C}$ temperature. The formation of pure $\mathrm{Co}_{3} \mathrm{O}_{4}$ was confirmed by XRD analysis (not shown).

For comparison, the carbon supported $\mathrm{Co}_{3} \mathrm{O}_{4}$ nanocomposite labelled as $\mathrm{Co}_{3} \mathrm{O}_{4} / \mathrm{C}$ was prepared by mixing $0.01 \mathrm{~g}$ of $\mathrm{Co}_{3} \mathrm{O}_{4}$ and $0.1 \mathrm{~g}$ of carbon powder in $20 \mathrm{ml}$ of deionized water. The synthesis of nanocomposite was also carried out at the same conditions.

\section{Characterization of nanocomposites}

The morphology and composition of the prepared catalysts were characterized using a SEMfocused ion beam facility (Helios Nanolab 650) equipped with an EDX spectrometer (INCA Energy 350 X-Max 20). A shape and size of catalyst particles were examined using a transmission electron microscope Tecnai G2 F20 X-TWIN equipped with an EDX spectrometer with an r-TEM detector. For microscopic examinations, $10 \mathrm{mg}$ of the sample was first sonicated in $1 \mathrm{ml}$ of ethanol for $1 \mathrm{~h}$ and then deposited on the Ni grid covered with a continuous carbon film. Mn and Co loadings in the prepared samples were estimated using an ICP optical emission spectrometer Optima 7000DV (Perkin Elmer).

\section{Electrochemical measurements}

The electrochemical performance of $\mathrm{MnO}_{2}-\mathrm{Co}_{3} \mathrm{O}_{4} /$ $\mathrm{C}$ and $\mathrm{Co}_{3} \mathrm{O}_{4} / \mathrm{C}$ nanocomposites was tested using a Zennium electrochemical workstation (ZAHNER-Elektrik GmbH \& Co. KG). The prepared nanocomposites coated on the glassy carbon electrode (GCE) with a geometric surface area of $0.07 \mathrm{~cm}^{2}$ were employed as a working electrode, a Pt sheet as a counter electrode, and an $\mathrm{Ag} / \mathrm{AgCl} / \mathrm{KCl}$ electrode was used as a reference. The working electrodes were prepared as follows: $10 \mathrm{mg}$ of the prepared nanocomposites were dispersed ultrasonically in $0.1 \mathrm{ml}$ of $2 \%$ of polyvinylidene fluoride (PVDF) in an N-methyl-2-pyrrolidinone (NMP) solution for $1 \mathrm{~h}$. Then, $5 \mu \mathrm{L}$ of the prepared suspension mixture was pipetted onto the polished surface of GCE and dried in an oven for $2 \mathrm{~h}$ at $80^{\circ} \mathrm{C}$.

Cyclic voltammograms (CVs) were recorded in a $1 \mathrm{M} \mathrm{Na}_{2} \mathrm{SO}_{4}$ solution at different scan rates between 10 and $200 \mathrm{mV} \mathrm{s}^{-1}$ at ambient temperature. The measuring potential range was from 0.05 to $1.10 \mathrm{~V}$. All solutions were deaerated by argon for 15 min prior to measurements.

\section{RESULTS AND DISCUSSION}

The surface morphology of the prepared $\mathrm{MnO}_{2}-$ $\mathrm{Co}_{3} \mathrm{O}_{4} / \mathrm{C}$ nanocomposites was investigated by SEM analyses. Figure 1 shows the SEM images of $\mathrm{MnO}_{2}-$ $\mathrm{Co}_{3} \mathrm{O}_{4} / \mathrm{C}-1(\mathrm{a}, \mathrm{b})$ and $\mathrm{MnO}_{2}-\mathrm{Co}_{3} \mathrm{O}_{4} / \mathrm{C}-2$ (c, d) under different magnification. The use of different precursor materials for the synthesis of the carbon supported $\mathrm{MnO}_{2}$ and $\mathrm{Co}_{3} \mathrm{O}_{4}$ nanocomposites results in a different morphology of the prepared ones. As evident from Fig. 1 $1 \mathrm{a}$ and $\mathrm{b}$, the $\mathrm{MnO}_{2}-\mathrm{Co}_{3} \mathrm{O}_{4} / \mathrm{C}-1$ nanocomposite has a spatial layer of irregularly shaped lamellar nanostructures of ca. $10-50 \mathrm{~nm}$ in size. Meanwhile, in the case of $\mathrm{MnO}_{2}-\mathrm{Co}_{3} \mathrm{O}_{4} / \mathrm{C}-2$ nanocomposite, the spongy and porous frost-like three-dimensional surface is observed (Fig. 11 c, d). The widely sprayed branches range from several to hundred $\mathrm{nm}$ in size.

More detailed microstructural information of the synthesized $\mathrm{MnO}_{2}-\mathrm{Co}_{3} \mathrm{O}_{4} / \mathrm{C}$ nanocomposites has been provided by TEM analysis and are shown in Fig. 1 $\mathrm{e}-\mathrm{h}$. The obtained data are in line with those determined by SEM analysis. In the case of $\mathrm{MnO}_{2}-$ $\mathrm{Co}_{3} \mathrm{O}_{4} / \mathrm{C}-1$ nanocomposite, tapered nanowires and nanosheets are almost uniformly distributed on the surface (Fig. 11e, f). Moreover, the aggregated spherical nanostructures composed of oblong branches are seen in the prepared $\mathrm{MnO}_{2}-\mathrm{Co}_{3} \mathrm{O}_{4} / \mathrm{C}-2$ nanocomposite (Fig. 1 $1 \mathrm{~g}, \mathrm{~h}$ ). 

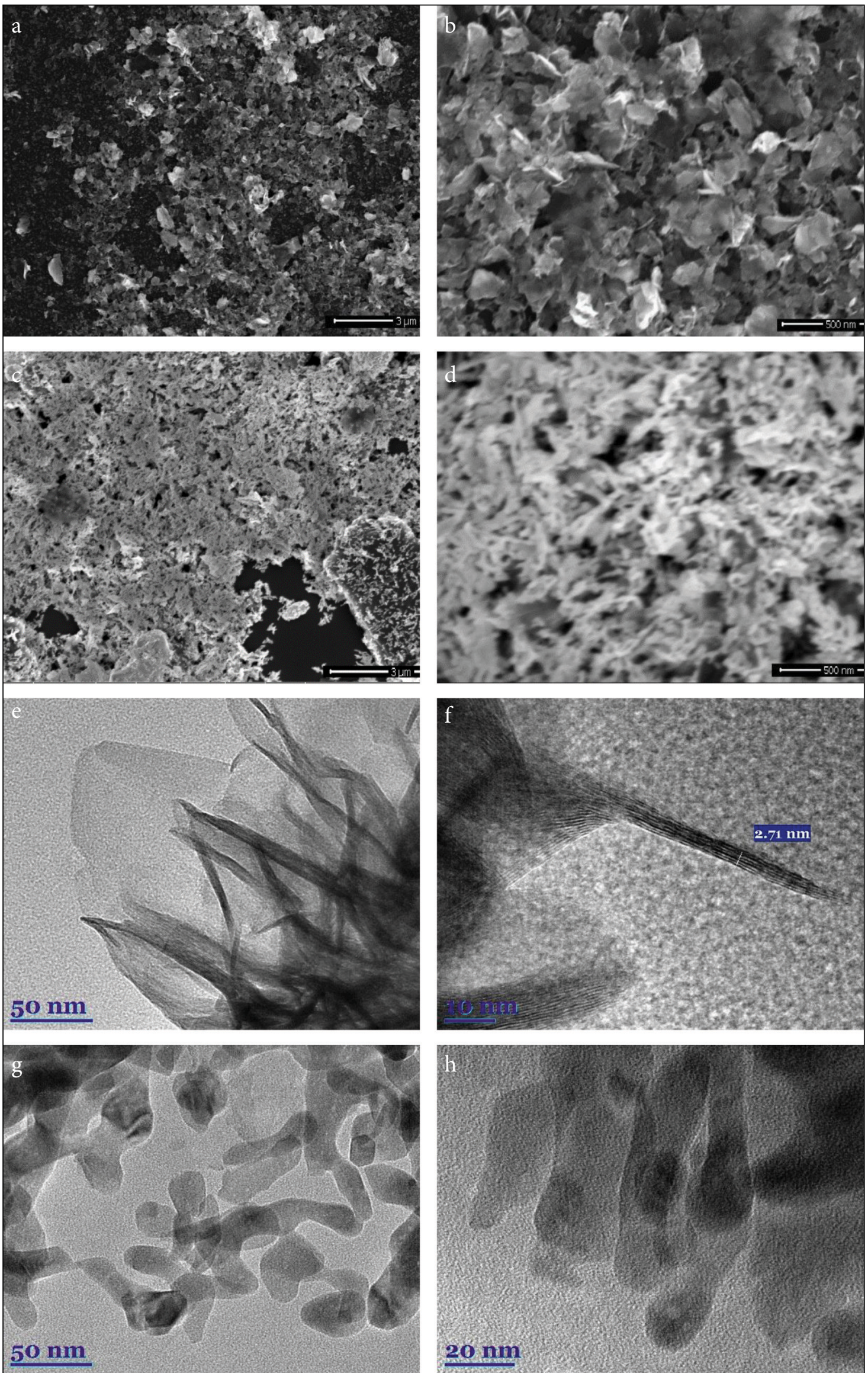

Fig. 1. SEM and TEM images of $\mathrm{MnO}_{2}-\mathrm{Co}_{3} \mathrm{O}_{4} /\left(-1(a, b, e, f)\right.$ and $\mathrm{MnO}_{2}-\mathrm{CO}_{3} \mathrm{O}_{4} /(-2(c, d, g, h)$ under different magnifications 
The electrochemical performance of the $\mathrm{MnO}_{2}-$ $\mathrm{Co}_{3} \mathrm{O}_{4} / \mathrm{C}$ nanocomposites was evaluated from the cyclic voltammetry using a three-electrode system in an aqueous $1 \mathrm{M} \mathrm{Na}_{2} \mathrm{SO}_{4}$ electrolyte. Figure 2 presents the CVs of $\mathrm{MnO}_{2}-\mathrm{Co}_{3} \mathrm{O}_{4} / \mathrm{C}-1$ (a), $\mathrm{MnO}_{2}-$ $\mathrm{Co}_{3} \mathrm{O}_{4} / \mathrm{C}-2(\mathrm{~b})$ and $\mathrm{Co}_{3} \mathrm{O}_{4} / \mathrm{C}(\mathrm{c})$ at scan rates of $10,50,100$ and $200 \mathrm{mV} \mathrm{s}^{-1}$ in a potential window of 0.05 to $1.1 \mathrm{~V}$ vs SHE. The CVs of all the nanocomposites at a scan rate of $10 \mathrm{mV} \mathrm{s}^{-1}$ are shown in Fig. 2d. As evident, the all prepared nanocomposites show a quasi-rectangular and symmetric voltammetry curves at a low scan rate, indicating their good capacitive behaviour (Fig. 2d). Notably, with increasing scan rate up to $200 \mathrm{mV} \mathrm{s}^{-1}$, the current density values increase gradually, but CVs do not always maintain a rectangular shape, especially at a high scan rate (Fig. 2a-c). The CV area of $\mathrm{MnO}_{2}-\mathrm{Co}_{3} \mathrm{O}_{4} / \mathrm{C}-2$ nanocomposite is larger than that of $\mathrm{MnO}_{2}-\mathrm{Co}_{3} \mathrm{O}_{4} / \mathrm{C}-1$ and $\mathrm{Co}_{3} \mathrm{O}_{4} / \mathrm{C}$ (Fig. 20 d). This result suggests that the specific capacitance of $\mathrm{MnO}_{2}-\mathrm{Co}_{3} \mathrm{O}_{4} / \mathrm{C}-2$ nanocomposite is higher as compared with that for $\mathrm{MnO}_{2}-\mathrm{Co}_{3} \mathrm{O}_{4} / \mathrm{C}-1$ and $\mathrm{Co}_{3} \mathrm{O}_{4} / \mathrm{C}$ nanocomposites. $\mathrm{C}_{\mathrm{s}}\left(\mathrm{F} \mathrm{g}^{-1}\right)$ of the electrode material was calculated from the $\mathrm{CV}$ test according to the following equation (Eq. 1) [41]:

$$
C_{s}=\frac{1}{m \cdot v \cdot \Delta V} \int i d v .
$$

Here $C_{s}$ is the specific capacitance $\left(\mathrm{F} \mathrm{g}^{-1}\right), m$ is the mass of the active material $(\mathrm{g}), v$ is the scan rate of potential $\left(\mathrm{V} \mathrm{s}^{-1}\right), \Delta \mathrm{V}$ is the range of scan potential $(\mathrm{V})$, and $i$ is the current (A). Plots of $C_{\mathrm{s}}$ versus scan rate for $\mathrm{MnO}_{2}-\mathrm{Co}_{3} \mathrm{O}_{4} / \mathrm{C}-1, \mathrm{MnO}_{2}-\mathrm{Co}_{3} \mathrm{O}_{4} / \mathrm{C}-2$ and $\mathrm{Co}_{3} \mathrm{O}_{4} / \mathrm{C}$ are presented in Fig. 3. It is clearly seen that the $C_{s}$ values of all the nanocomposites decrease with the growth of scan rate from 10 to $200 \mathrm{mV} \mathrm{s}^{-1}$,

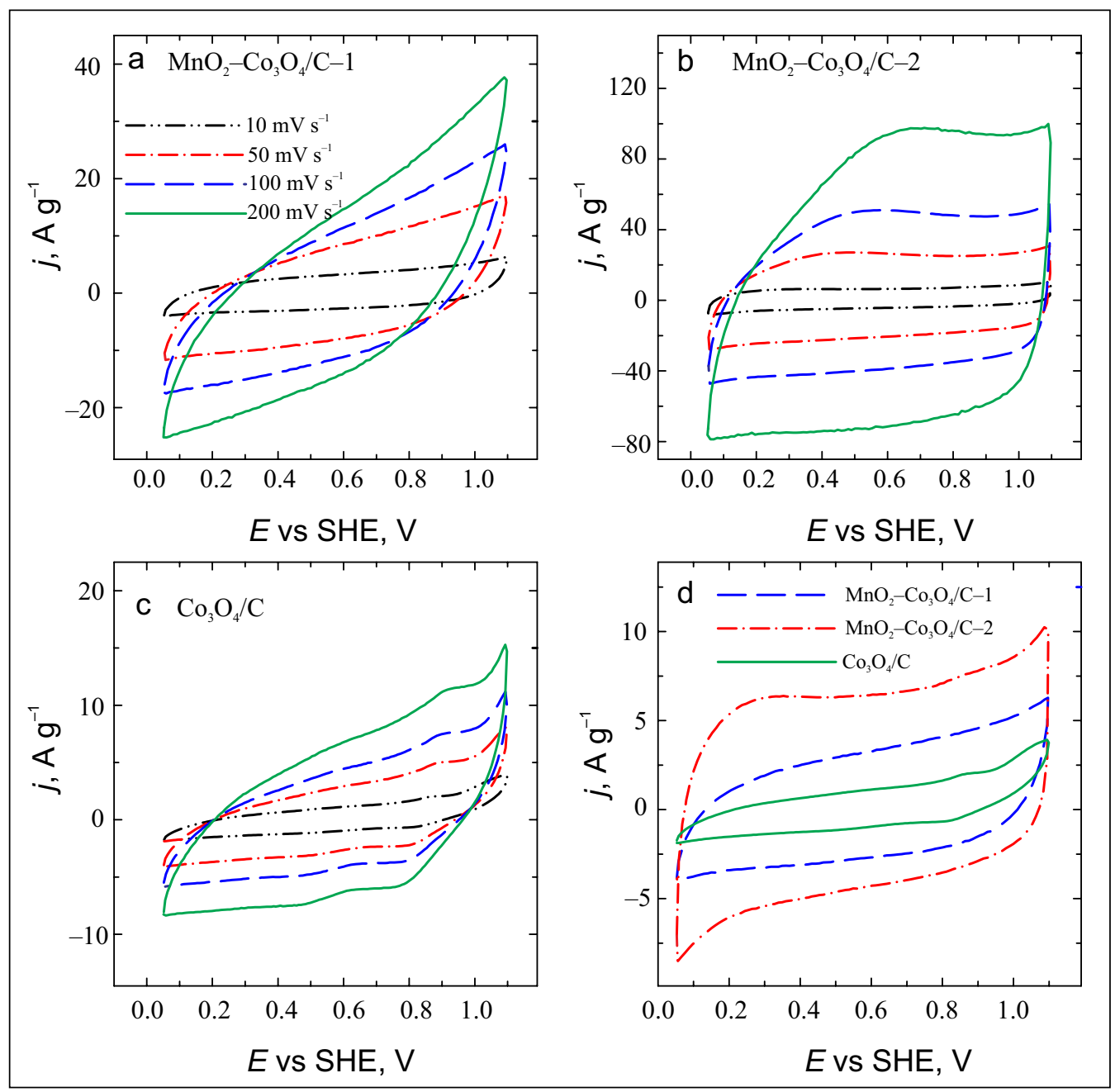

Fig. 2. CVs of $\mathrm{MnO}_{2}-\mathrm{CO}_{3} \mathrm{O}_{4} / \mathrm{C}-1$ (a), $\mathrm{MnO}_{2}-\mathrm{CO}_{3} \mathrm{O}_{4} / \mathrm{C}-2$ (b) and $\mathrm{CO}_{3} \mathrm{O}_{4} / \mathrm{C}$ (c). (d) CVs of the same nanocomposites at a scan rate of $10 \mathrm{mV} \mathrm{s}^{-1}$ 


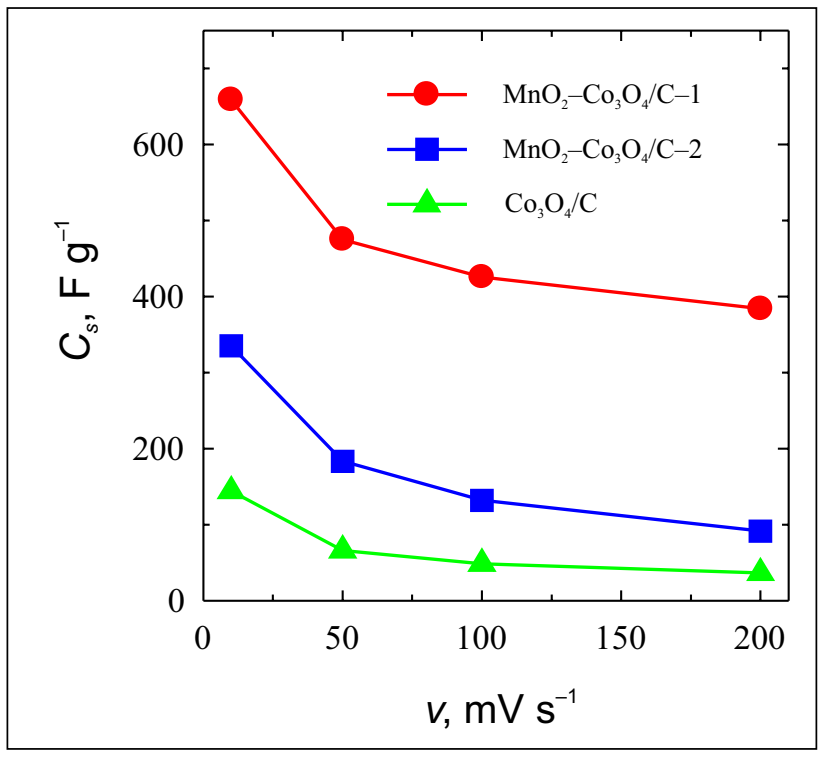

Fig. 3. Plots of the specific capacitance versus scan rate of $\mathrm{MnO}_{2}-\mathrm{CO}_{3} \mathrm{O}_{4} / \mathrm{C}-1, \mathrm{MnO}_{2}-\mathrm{CO}_{3} \mathrm{O}_{4} / \mathrm{C}-2$ and $\mathrm{CO}_{3} \mathrm{O}_{4} / \mathrm{C}$ nanocomposites

nevertheless the $C_{\mathrm{s}}$ values of the nanocomposites are still higher. The calculated $C_{s}$ value for the $\mathrm{MnO}_{2}-\mathrm{Co}_{3} \mathrm{O}_{4} / \mathrm{C}-2$ nanocomposite is highest at a scan rate of $10 \mathrm{mV} \mathrm{s}^{-1}$ among the investigated nanocomposites and equal to $658.8 \mathrm{~F} \mathrm{~g}^{-1}$ (Fig. 3). This value is much larger than that of $\mathrm{MnO}_{2}-\mathrm{Co}_{3} \mathrm{O}_{4} / \mathrm{C}-1\left(335.0 \mathrm{~F} \mathrm{~g}^{-1}\right)$ and pure $\mathrm{Co}_{3} \mathrm{O}_{4} / \mathrm{C}$ $\left(144.1 \mathrm{~F} \mathrm{~g} \mathrm{~g}^{-1}\right)$. When the scan rate increases to $200 \mathrm{mVs}^{-1}$, the $\mathrm{MnO}_{2}-\mathrm{Co}_{3} \mathrm{O}_{4} / \mathrm{C}-1, \mathrm{MnO}_{2}-\mathrm{Co}_{3} \mathrm{O}_{4} / \mathrm{C}-2$ and $\mathrm{Co}_{3} \mathrm{O}_{4} / \mathrm{C}$ nanocomposites still exhibit $\mathrm{Cs}$ of 91.6, 384.2 and $36.7 \mathrm{~F} \mathrm{~g}^{-1}$, respectively (Fig. 3). The $\mathrm{MnO}_{2}-\mathrm{Co}_{3} \mathrm{O}_{4} / \mathrm{C}-1, \quad \mathrm{MnO}_{2}-\mathrm{Co}_{3} \mathrm{O}_{4} / \mathrm{C}-2$ and $\mathrm{Co}_{3} \mathrm{O}_{4} / \mathrm{C}$ nanocomposites preserve $27.3,58.3$ and
$25.5 \%$, respectively, of their specific capacitance (from $335.0 \mathrm{~F} \mathrm{~g}^{-1}$ to $91.6 \mathrm{~F} \mathrm{~g}^{-1}$, from $658.8 \mathrm{~F} \mathrm{~g}^{-1}$ to $384.2 \mathrm{~F} \mathrm{~g}^{-1}$, and from $144.1 \mathrm{~F} \mathrm{~g}^{-1}$ to $36.7 \mathrm{~F} \mathrm{~g}^{-1}$ ) as the scan rate increases from $10 \mathrm{mV} \mathrm{s}^{-1}$ to $200 \mathrm{mV} \mathrm{s}^{-1}$.

Comparison of the supercapacitive behaviour of $\mathrm{MnO}_{2}$ nanocomposites reported in literature and the present work are listed in the Table, exhibiting the high specific capacitance of our prepared electrode materials.

\section{CONCLUSIONS}

In this study, we report a rapid synthesis of the carbon supported $\mathrm{MnO}_{2}$ and $\mathrm{Co}_{3} \mathrm{O}_{4}$ nanocomposites via a simple and facile microwave-assisted heating method without any complicated extra-posttreatment procedures. The application of different precursor materials for the preparation of carbon supported $\mathrm{MnO}_{2}-\mathrm{Co}_{3} \mathrm{O}_{4}$ determines directly the formation of nanocomposites having different morphology such as irregularly shaped lamellar or spherical nanostructures that have a decisive impact on the electrochemical performance. The highest specific capacitance of $658.8 \mathrm{~F} \mathrm{~g}^{-1}$ at a scan rate of $10 \mathrm{mV} \mathrm{s}^{-1}$ has been achieved at the $\mathrm{MnO}_{2}-\mathrm{Co}_{3} \mathrm{O}_{4} / \mathrm{C}-2$ nanocomposite that has a spherically shaped nanoparticle architecture in comparison with that of $\mathrm{MnO}_{2}-\mathrm{Co}_{3} \mathrm{O}_{4} / \mathrm{C}-1$ with a lamellar shape structure. The prepared $\mathrm{MnO}_{2}-\mathrm{Co}_{3} \mathrm{O}_{4}$ nanocomposites are expected to be a promising electrode material for supercapacitor applications.

Table. Comparison of $\mathrm{Cs}$ for various $\mathrm{MnO}_{2}$-based electrode materials

\begin{tabular}{|c|c|c|c|}
\hline Materials & $\begin{array}{c}\text { Scan rate, current } \\
\text { density }\end{array}$ & $\begin{array}{l}\text { Specific capacitance, } \\
\text { F g }^{-1}\end{array}$ & Ref. \\
\hline $\mathrm{MnO}_{2}-\mathrm{Co}_{3} \mathrm{O}_{4} / \mathrm{C}-1$ & $10 \mathrm{mV} \mathrm{s}^{-1}$ & 335.0 & This work \\
\hline $\mathrm{MnO}_{2}-\mathrm{Co}_{3} \mathrm{O}_{4} / \mathrm{C}-2$ & $10 \mathrm{mV} \mathrm{s}^{-1}$ & 658.8 & This work \\
\hline Co-doped $\mathrm{MnO}_{2}$ & $10 \mathrm{mV} \mathrm{s}^{-1}$ & 287.0 & [29] \\
\hline $\mathrm{Co}_{3} \mathrm{O}_{4} @ \mathrm{PPy} @ \mathrm{MnO}_{2}$ & $2 \mathrm{mV} \mathrm{s}^{-1}$ & 518.0 & [33] \\
\hline $\begin{array}{l}\text { Biomorphic } \mathrm{Co}_{3} \mathrm{O}_{4} \text { nanocrystal/mesoporous car- } \\
\text { bon microtube composites }\end{array}$ & $1 \mathrm{Ag}^{-1}$ & 284.2 & [11] \\
\hline Hollow coral-shaped $\mathrm{Co}_{3} \mathrm{O}_{4}$ nanostructures & $5 \mathrm{mV} \mathrm{s}^{-1}$ & 626.5 & [12] \\
\hline $\mathrm{Co}_{3} \mathrm{O}_{4}$ core-shell microspheres & $0.5 \mathrm{Ag}^{-1}$ & 261.1 & [13] \\
\hline Au-doped $\mathrm{MnO}_{2}$ & $5 \mathrm{mV} \mathrm{s}^{-1}$ & 626.0 & [24] \\
\hline Cobalt-doped $\mathrm{MnO}_{2}$ hierarchical yolk-shell spheres & $0.1 \mathrm{~A} \mathrm{~g}^{-1}$ & 350 & [29] \\
\hline Flower-like $\mathrm{Co}_{3} \mathrm{O}_{4} @ \mathrm{MnO}_{2}$ core-shell composite & $1 \mathrm{Ag}^{-1}$ & 671 & [36] \\
\hline
\end{tabular}




\section{ACKNOWLEDGEMENTS}

This research is funded by the European Social Fund under Measure No. 09.3.3-LMT-K-712-02-0142 'Development of Competences of Scientists, other Researchers and Students through Practical Research Activities'.

Received 17 March 2020 Accepted 19 March 2020

\section{References}

1. F. Wang, X. Wu, X. Yuan, et al., Chem. Soc. Rev., 46, 6854 (2017).

2. C. Liu, X. Yan, F. Hu, et al., Adv. Mater., 30, 1705713 (2018).

3. Poonam, K. Sharma, A. Arora, S. K. Tripathi, J. Energy Storage, 21, 825 (2019).

4. C. V. V. Muralee Gopi, R. Vinodh, S. Sambasivam, et al., J. Energy Storage, 27, 101035 (2020).

5. G. Wang, L. Zhang, J. Zhang, Chem. Soc. Rev., 41, 797 (2012).

6. L. L. Liu, Z. Q. Niu, J. Chen, Chem. Soc. Rev., 45, 4363 (2016).

7. K. Bazaka, M. V. Jacob, K. Ostrikov, Chem. Rev. 116, 214 (2016).

8. F. Lai, Y. E. Miao, L. Zuo, et al., Small, 12, 3199 (2016).

9. A. Muzaffar, M. Basheer Ahamed, K. Deshmukha, et al., Renew. Sustain. Energy Rev. 101, 145 (2019).

10. A. Afif, S. M. H. Rahman, A. T. Azad, et al., J. Energy Storage, 25, 100852 (2019).

11. D. Sun, L. Hea, R. Chen, et al., Appl. Surf. Sci. 465, 240 (2019).

12. X. Wang, N. Zhang, X. Chen, et al., Colloids Surf. A, 570, 72 (2019).

13. D. Guo, X. Song, F. Li, et al., Colloids Surf. A, 546, 8 (2018).

14. W. Guo, C. Yu, S. Li, et al., Nano Energy, 57, 472 (2019).

15. J.-G. Wang, F. Kang, B. Wei, Prog. Mater. Sci., 74, 124 (2015).

16. C. D. Lokhande, D. P. Dubal, O.-S. Joo, Curr. Appl. Phys., 11, 270 (2011).

17. X. Guo, G. Zhang, Q. Li, et al., Energy Stor. Mater., 15, 201 (2018).
18. M. Huang, Y. Zhang, F. Li, et al., Sci. Rep., 4, 3886 (2014).

19. B. Yin, S. Zhang, Y. Jiao, et al., Cryst Eng Comm., 16, 10005 (2014).

20. J. Chu, D. Lu, J. Ma, et al., Mater. Lett., 193, 265 (2017).

21. M. Pal, R. Rakshit, A. K. Singh, et al., Energy, 103, 486 (2016).

22. X. Pan, X. Chen, Y. Li, et al., Electrochim. Acta, 182, 1106 (2015).

23. Q. Lv, H. Sun, X. Li, et al., Nano Energy, 21, 50 (2016).

24. J. Kang, A. Hirata, L. Kang, et al., Chem. Int. Ed., 52, 1667 (2013).

25. Z. M. Hu, X. Xiao, C. Chen, et al., Nano Energy, 11, 234 (2015).

26. X. Su, L. Yu, G. Cheng, et al., Appl. Energy, 134, 445 (2014).

27. R. Peng, N. Wu, Y. Zheng, et al., ACS Appl. Mater. Interf., 8, 8480 (2016).

28. Z. Wang, F. Wang, Y. Li, et al., Nanoscale, 8, 7317 (2016).

29. C.-L. Tang, X. Wei, Y.-M. Jiang, et al., J. Phys. Chem. C., 119, 8471 (2015).

30. A. M. Hashem, H. M. Abuzeid, N. Narayanan, et al., Mater. Chem. Phys., 130, 38 (2011).

31. Q. Meng, W. Xu, S. Zhu, et al., Electrochim. Acta, 296, 205 (2019).

32. A. E. Elkholy, F. El-Taib Heakal, N. K. Allam, Electrochim. Acta, 296, 68 (2019).

33. L. Han, P. Tang, L. Zhang, Nano Energy, 7, 51 (2014).

34. F. Wang, Q. Zhou, G. Li, et al., J. Alloys Compd., 700, 190 (2017).

35. H. Wang, Q. Ren, J. L. Brett Dan, et al., J. Power Sources, 343, 82 (2017).

36. H. Che, Y. Lv, A. Liu, et al., Ceram. Int., 43, 6062 (2017).

37. Y. Zou, C. Cai, C. Xiang, et al., Electrochim. Acta, 261, 547 (2018).

38. Y. Chen, C. Jing, X. Fu, et al., Appl. Surf. Sci., 503, 144123 (2020).

39. L. Huang, W. Zhang, J. Xiang, et al., Sci. Rep., 6, 31465 (2016).

40. X. Wang, Q. Zhang, J. Sun, et al., J. Mater. Chem. A, 6, 8038 (2018).

41. X. Meng, L. Lu, C. Sun, ACS Appl. Mater. Interf., 10, 16481 (2018). 


\author{
Jolita Jablonskienè, Dijana Šimkūnaitè, \\ Jūratė Vaičiūnienè, Giedrius Stalnionis, \\ Audrius Drabavičius, \\ Loreta Tamašauskaitė-Tamašiūnaitè, \\ Eugenijus Norkus
}

\title{
MANGANO(IV)-KOBALTO(II/III) OKSIDU, SUFORMUOTU ANT ANGLIES PAGRINDO, TAIKYMAS ELEKTROCHEMINIAMS SUPERKONDENSATORIAMS
}

Santrauka

Naudojant iš skirtingų prekursorių susintetintus $\mathrm{MnO}_{2}$ ir $\mathrm{Co}_{3} \mathrm{O}_{4}, \mathrm{MnO}_{2}-\mathrm{Co}_{3} \mathrm{O}_{4} / \mathrm{C}$ nanokompozitai buvo formuojami ant anglies pagrindo taikant mikrobangu sintezès metodą. Skirtingais būdais suformuotų nanokompozitu morfologija ir sudètis buvo tiriami naudojant skenuojančiąją elektronų mikroskopiją (SEM), peršviečiamąją elektroninę mikroskopiją (TEM) ir indukciškai susietos plazmos optinès emisijos spektroskopiją (ICP-OES). $\mathrm{MnO}_{2}-\mathrm{Co}_{3} \mathrm{O}_{4} / \mathrm{C}$ nanokompozitu elektrocheminè elgsena buvo tiriama taikant ciklinę voltamperometriją (CV).

Nustatyta, kad sintezès metu susidarančiu nanokompozitu paviršiaus morfologija priklauso nuo naudotų prekursorių prigimties. Kai sintezejje buvo naudojamas $\mathrm{Co}_{3} \mathrm{O}_{4}$, gaunamas $\mathrm{MnO}_{2}-\mathrm{Co}_{3} \mathrm{O}_{4} / \mathrm{C}-2$ nanokompozitas, kuriam yra būdingos sferinès formos nanodalelès. $1 \mathrm{M} \mathrm{Na}_{2} \mathrm{SO}_{4}$ tirpale, kai potencialo skleidimo greitis buvo $10 \mathrm{mV} \mathrm{s}^{-1}$, išmatuotoji didžiausia specifinès talpos $\left(C_{\mathrm{s}}\right)$ vertè sieké $658,8 \mathrm{~F} \mathrm{~g}^{-1}$. Be to, pastarasis nanokompozitas pasižymi žymiai geresnèmis katalizinèmis savybėmis nei $\mathrm{MnO}_{2}-\mathrm{Co}_{3} \mathrm{O}_{4} / \mathrm{C}-1$ nanokompozitas (šiuo atveju kaip prekursorius buvo naudojamas $\left.\mathrm{Co}\left(\mathrm{NO}_{3}\right)_{2}\right)$, kuriam būdingos plokštelinès formos nanodalelès. 